\title{
Treatment and prevention of infection following bites of the Antarctic fur seal (Arctocephalus gazella)
}

This article was published in the following Dove Press journal:

Open Access Emergency Medicine

2 April 2015

Number of times this article has been viewed

\section{Timur Kouliev'}

Victoria Cui ${ }^{2}$

'Beijing United Family Hospital, Beijing, People's Republic of China; ${ }^{2}$ Department of Biological Sciences, Columbia University, New York, NY, USA
Correspondence: Victoria Cui 640 I Deer Hollow Lane, Austin, TX, USA

Tel + I 5122893718

Email cui.victoria@gmail.com
Abstract: In recent decades, an increasing number of people have traveled to sub-Antarctic and Antarctic regions each year for research, tourism, and resource exploitation. Hunting of Antarctic fur seals (Arctocephalus gazella) almost pushed the species to extinction in the early 1900 s, but populations have since shown rapid and substantial recovery. The species' range has re-expanded to include several islands south of the Antarctic Convergence, most notably South Georgia, and now overlaps with many popular Antarctic travel destinations. Both male and female fur seals can become extremely aggressive when provoked, and their bites, if not properly treated, pose a significant risk of infection by microorganisms not usually encountered in cases of animal bites. In this report, we present the case of a patient treated for a fur seal bite during an Antarctic expedition cruise, review the literature concerning seal bites, and suggest the use of antibiotic prophylaxis to prevent complications.

Keywords: zoonotic, polar tourism, prophylaxis, seal finger, expedition medicine

\section{Introduction}

An increasing number of tourists and research scientists travel to sub-Antarctic and Antarctic regions each year during the austral summer of November to March. ${ }^{1}$ The growing trend of international travel and ecotourism to remote destinations has led to a concurrent increase in injuries previously considered "exotic" and calls for specific medical background, experience, and approaches to treatment.

The range of the Antarctic fur seal (Arctocephalus gazella) overlaps with popular Antarctic tourist destinations and predominately comprises islands south of the Antarctic Convergence and north of $60 \mathrm{~S}$ latitude. ${ }^{2}$ During the early 1900 s, the fur seal was almost hunted to extinction for its thick fur pelt. Populations in recent decades have shown extremely rapid and substantial recovery, with an estimated population size exceeding 4 million individuals on the seasonally ice-free island of South Georgia. ${ }^{2-5}$ The fur seal's major breeding sites center on the beaches of South Georgia and have since re-expanded to include Signy Island, Bird Island, Livingston Island, Macquarie Island, and the South Shetland Islands. ${ }^{3,6-8}$ Following the breeding period, males range farther to avoid foraging competition with females, with significant population density at South Orkney Island, Patagonia, and the west coast of the Antarctic Peninsula., During the fur seals' breeding and pupping seasons, which span the warm months of November to mid-April and coincide with the peak tourism season of November to March, entire island coastlines can be covered by the animals., 3

The complexity of the animals' behavior, severity of injuries, and potential for complications can make treatment of fur seal bites a challenge for physicians. While the 
relevant microflora, incidence, and treatment of dog and cat bite wounds have been well-documented and studied, fur seal bites have not been fully investigated. Because fur seals are aquatic animals, their bites reflect both the marine environment and specific food sources. ${ }^{11}$ Although the oral flora of fur seals has not yet been characterized, atypical microorganisms have been isolated from cases of non-Antarctic fur seal bites, including sealpox virus from the family Parapoxviridae, the bacteria species Bisgaardia hudsonensis, Erysipelothrix rhusiopathiae, and the newly discovered Streptococcus halichoeri, as well as several strains of Mycoplasma associated with the condition known as "seal finger". ${ }^{12-17}$ In this paper, we report the case of a patient attacked by an Antarctic fur seal, review existing literature regarding treatment of animal bites and related conditions such as seal finger, and discuss the implications for future guidelines in wilderness and emergency medicine.

\section{Case report}

A 74-year-old passenger of a polar expedition cruise landed on Deception Island in the South Shetland Islands for a day excursion. Prior to the outing, the expedition team gave a training session on proper behavior around wildlife ashore, which includes not turning one's back or running from fur seals on land. While exploring the island, the patient approached within 1-2 m of a large male animal, became frightened, and attempted to run. The fur seal pursued and outran the patient, lunged at him from behind, bit the patient on the right buttock, then immediately loosened its jaws and ran away.

The patient was seen by the expedition doctor on land and was observed as having a large defect in his outer shell pants and inner insulated trousers. There was a moderate amount of blood in the clothes and shoes. The patient was transferred to the expedition ship by Zodiac boat. Further physical examination revealed multiple puncture wounds of $0.5-1 \mathrm{~cm}$ in size, no tissue flaps, no obvious damage to underlying muscle, and no foreign body in a bloodless field exam. The distal extremity exam demonstrated normal strength, sensation, and perfusion.

The wound was irrigated with several liters of physiological solution and where possible, nonviable tissue was debrided under local anesthesia. There were no wounds that were amenable to repair given the type of injury. The wounds were dressed with topical mupirocin ointment, and due to significant contamination at the injury site and difficulty in irrigating the puncture wounds, this application was followed by intramuscular injection of $1 \mathrm{~g}$ of intramuscular ceftriaxone.
Following standard emergency medicine practice, $875 \mathrm{mg}$ oral amoxicillin/clavulanic acid was also given twice daily for 7 days. Dressings were changed daily and due to the extensive subsequent inflammatory reaction in the area, daily intramuscular $1 \mathrm{~g}$ doses of ceftriaxone were continued for two more days following the injury.

The patient disembarked 3 days following the event after having learned how to dress the bite wounds himself with assistance from family. At this point, the inflammatory reaction at the injury site had improved and the patient was advised to follow-up with his primary care physician once he returned home the next day. On 2 months' follow-up, the patient reported healing of the wound without further complications.

\section{Discussion}

Breeding populations of Antarctic fur seals are highly polygynous and organized into land-based harems of adult females guarded by dominant territorial males. Due to the extreme site fidelity shown by fur seals, animals in these breeding groups can be very densely grouped. ${ }^{8}$ Competition for space and mates is fierce, and the $125-200 \mathrm{~kg}$ males remain alert and aggressive toward all intruders, including humans, and can attack with little to no obvious provocation. Female fur seals, while smaller in size, are likewise extremely protective of their pups and have a relatively long duration of maternal attendance behavior, presenting risk for individuals who may inadvertently come between them. ${ }^{18}$ On land, fur seals are surprisingly agile due to the forward orientation of their hind flippers, a trait shared with other otariid pinnipeds, and can move at up to $20 \mathrm{kph}(12 \mathrm{mph})$ in short bursts, easily outrunning most humans. ${ }^{19}$

Human bite wound infections from bites inflicted by dogs, cats, and various other animals often feature multiple strains of aerobic and anaerobic microorganisms. The bacteria isolated reflect both the microflora of the animals' oral cavities and that of their food sources, as well as the victim's skin and physical environment. ${ }^{11}$ Streptococcus and Staphylococcus species, Pasteurella multocida, and Capnocytophaga canimorsus are some of the pathogens most commonly isolated from bite wounds from dogs and cats, and thus are encountered most often by physicians. ${ }^{20}$ In bites inflicted by marine animals like the Antarctic fur seal, less commonly encountered microorganisms should be anticipated due to the animals' aquatic environment and species-specific prey sources. Strains of Erysipelothrix rhusiopathiae, Micrococcus sp., and Bisgaardia hudsonensis have each been isolated from infected seal bites, while 
Vibrio, Pseudomonas, and Mycobacterium are commonly reported in bites inflicted by other marine animals. ${ }^{12,14,15,17,21,22}$ The zoonotic potential of viruses has also been confirmed in the case of a patient who developed an orf-like sealpox lesion caused by a member of the family Parapoxviridae following a definite bite by a young gray seal (Halichoerus grypus) treated by Clark et al. ${ }^{13}$ Infection of seal bites by these microorganisms, along with enteric Campylobacter insulaenigrae and Campylobacter lari isolated from fecal samples of asymptomatic fur seals, may also reflect significant anthropogenic "microbial pollution.",23

The condition known as "seal finger" or "spekk" is well-documented as the result of bites from other species of seal and has been reported as a common injury suffered by sealers, with infection caused by any of several species of Mycoplasma. If left untreated, seal finger can result in severe pain, intense swelling, and joint involvement that can progress to cellulitis, tenosynovitis, and septic arthritis. ${ }^{12,16,24}$ In a case examined by Baker et al, Mycoplasma phocacerebrale isolated from the wound site demonstrated resistance to erythromycin, clindamycin, vancomycin, and gentamicin while responding to tetracycline, ciprofloxacin, and chloramphenicol. ${ }^{24}$ However, the fur seal bite discussed in our case report is distinguished from seal finger by species, bite location, and severity of the initial injury. Sealers, marine biologists, and wildlife veterinarians make up the majority of cases of seal finger due to the close contact with seals required by their occupations. ${ }^{16}$ It is possible that travelers are more at risk for the type of attack described here due to inexperience and the nature of their interaction with the animals.

Current recommendations suggest that animal bite wounds should be immediately treated like any laceration with washing, exploration for further tissue damage, irrigation, and debridement. ${ }^{25}$ As with any animal bite, suturing of the wound should be avoided except in unusual circumstances and with extreme caution. In the field, where advanced medical services may not be available, suturing should be even less common. Rabies and antibiotic prophylaxis is usually administered based on the animal responsible for the injury, and in the case of fur seal bite may be very important due to the unique oral bacterial population of fur seals. Indeed, in the cases of seal finger as described by Mass et al and White et al, patients were first misdiagnosed as having erysipeloid and not given the appropriate antibiotics due to lack of physician awareness of the infections associated with seal bites. ${ }^{12,16}$ The British Antarctic Survey currently recommends a course of metronidazole and doxycycline for fur seal bites suffered in South Georgia (C King, personal communication, 2014).
Additional treatment measures should be initiated depending on patient response and when more information such as bacterial culture and antibiotic response is obtained.

In addition to physician awareness, education of passengers in bite prevention is of utmost importance. Despite instructions, travelers may become intimidated by the number and size of fur seals on a beach and try to run, a reaction that can provoke aggression in the animals. Briefings with clear guidelines concerning appropriate distances, behavior, and mitigation strategies are essential for passengers traveling to the Antarctic and sub-Antarctic regions.

\section{Conclusion}

It is important to remember that Antarctic fur seals and other marine species can be affected by the expansion of Antarctic tourism. To prevent injury, travelers to the Antarctic region should vigilantly follow established guidelines, such as those put out by the International Association of Antarctic Tour Operators (IAATO), when approaching wildlife and interacting with fur seals. We suggest that physicians in Antarctica be aware of and exchange experiences regarding prevention, prophylaxis, and wound treatment for seal bites.

\section{Disclosure}

The authors report no conflicts of interest in this work.

\section{References}

1. Liggett D, McIntosh A, Thompson A, Gilbert N, Storey B. From frozen continent to tourism hotspot? Five decades of Antarctic tourism development and management, and a glimpse into the future. Tour Manage. 2011;32(2):357-366.

2. Acevedo J, Matus R, Droguett D, Vila A, Aguayo-Lobo A, Torres D. Vagrant Antarctic fur seals, Arctocephalus gazella, in southern Chile. Polar Biol. 2011;34(6):939-943.

3. Boyd IL. Pup production and distribution of breeding Antarctic fur seals (Arctocephalus gazella) at South Georgia. Antarc Sci. 1993; 5(1):17-24.

4. Hodgson DA, Johnston NM, Jones VJ. Palaeolimnology of Antarctic Fur Seal Arctocephalus gazella populations and implications for Antarctic management. Biol Conserv. 1998;83(2):145-154.

5. Croxall JP. The status and conservation of Antarctic seals and seabirds: a review. Environ Int. 1986;13(1):55-70.

6. Lewis Smith RI. Destruction of Antarctic terrestrial ecosystems by a rapidly increasing fur seal population. Biol Conserv. 1988;45(1):55-72.

7. Boyd IL, McCafferty DJ, Reid K, Taylor R, Walker TR. Dispersal of male and female Antarctic fur seals (Arctocephalus gazella). Can J Fish Aquat Sci. 1998;55(4):845-852.

8. Robinson SA, Goldsworthy SG, van den Hoff J, Hindell MA. The foraging ecology of two sympatric fur seal species, Arctocephalus gazella and Arctocephalus tropicalis, at Macquarie Island during the austral summer. Mar Freshwater Res. 2002;53(7):1071-1082.

9. Boyd IL, Staniland IJ, Martin AR. Distribution of foraging by female Antarctic fur seals. Mar Ecol Prog Ser. 2002;242:285-294.

10. Prociv P. Health aspects of Antarctic tourism. J Travel Med. 1998;5(4): 210-212.

11. Abrahamian FM, Goldstein EJ. Microbiology of animal bite wound infections. Clin Microbiol Rev. 2011;24(2):231-246. 
12. Mass DP, Newmeyer WL, Kilgore ES Jr. "Seal finger". J Hand Surg. 1981;6(6):610-612.

13. Clark C, McIntyre PG, Evans A, McInnes CJ, Lewis-Jones S. Human sealpox resulting from a seal bite: confirmation that sealpox virus is zoonotic. Br J Dermatol. 2005;152(4):791-793.

14. Davison NJ, Barnett JE, Ayling RD, Whatmore AM, Foster G. Isolation of Bisgaardia hudsonensis from a seal bite. J Infect. 2012; 64(2):231-232.

15. Sundeep S, Cleeve V. Isolation of Bisgaardia hudsonensis from a seal bite. Case report and review of the literature on seal finger. $J$ Infect. 2011;63(1):86-88.

16. White PW, Jewer DD. Seal finger: a case report and review of the literature. Can J Plastic Surg. 2009;17(4):133-135.

17. Foo RM, Chan D. A fishy tale: a man with empyema caused by Streptococcus halichoeri. J Clin Microbiol. 2014;52(2):681-682.

18. Goldsworthy S. Maternal attendance behaviour of sympatrically breeding Antarctic and subantarctic fur seals, Arctocephalus spp., at Macquarie Island. Polar Biol. 1999;21(5):316-325.
19. Saundry P. Antarctic fur seal. In: McClary M, editor. Encyclopedia of Life. Environmental Information Coalition; 2012.

20. Yaqub S, Bjørnholt JV, Hellum KB, Steinbakk M, Enger AE. [Bite wound infections]. Tidsskr Nor Laegeforen. 2004;124(24):3194-3196. Norwegian.

21. Hillenbrand FK. Whale finger and seal finger; their relation to erysipeloid. Lancet. 1953;1(6762):680-681.

22. Higgins R. Bacteria and fungi of marine mammals: a review. Can Vet J. 2000;41(2):105-116.

23. García-Peña FJ, Pérez-Boto D, Jiménez C, et al. Isolation and characterization of Campylobacter spp. from Antarctic fur seals (Arctocephalus gazella) at Deception Island, Antarctica. Appl Environ Microbiol. 2010;76(17):6013-6016.

24. Baker AS, Ruoff KL, Madoff S. Isolation of Mycoplasma species from a patient with seal finger. Clin Infect Dis. 1998;27(5): $1168-1170$.

25. Brook I. Management of human and animal bite wound infection: an overview. Curr Infect Dis Rep. 2009;11(5):389-395.

\section{Dovepress}

\section{Publish your work in this journal}

Open Access Emergency Medicine is an international, peer-reviewed, open access journal publishing original research, reports, editorials, reviews and commentaries on all aspects of emergency medicine. The manuscript management system is completely online and includes a very quick and fair peer-review system, which is all easy to use.

Submit your manuscript here: http://www.dovepress.com/open-access-emergency-medicine-journal
Visit http://www.dovepress.com/testimonials.php to read real quotes from published authors. 